\title{
Effects of pH, dissolved organic matter, and salinity on ibuprofen sorption on sediment
}

\author{
Sanghwa $\mathrm{Oh}^{1}{ }^{1}$ - Won Sik Shin ${ }^{2} \cdot$ Hong Tae $\mathrm{Kim}^{3}$
}

Received: 14 March 2016 / Accepted: 22 August 2016/Published online: 29 August 2016

(C) The Author(s) 2016. This article is published with open access at Springerlink.com

\begin{abstract}
Ibuprofen is well known as one of the most frequently detected pharmaceuticals and personal care products (PPCPs) in rivers. However, sorption of ibuprofen onto sediment has not been considered in spite of its high $K_{\text {ow }}$ (3.5). In this study, the effects of various environmental conditions such as $\mathrm{pH}(4,5.3$, and 7$)$, the concentrations of dissolved organic matters ( 0 to $1.0 \mathrm{mM}$ citrate and urea), salinity $(0,10,20$, and 30 part per thousand), and presence of other PPCP (salicylic acid) on ibuprofen sorption were investigated. Linear model mainly fitted the experimental data for analysis. The distribution coefficient $\left(K_{\mathrm{d}}\right)$ in the linear model decreased from 6.76 at $\mathrm{pH} 4$ to near zero at $\mathrm{pH} \mathrm{7,} \mathrm{indicating} \mathrm{that} \mathrm{neutral} \mathrm{form} \mathrm{of}$ ibuprofen at $\mathrm{pH}$ below $\mathrm{pKa}$ (5.2) was easily sorbed onto the sediment whereas the sorption of anionic form at $\mathrm{pH}$ over $\mathrm{pKa}$ was not favorable. To investigate the effect of dissolved organic matters (DOMs) on ibuprofen sorption, citrate and urea were used as DOMs. As citrate concentration increased, the $K_{\mathrm{d}}$ value decreased but urea did not interrupt the ibuprofen sorption. Citrate has three carboxyl functional groups which can attach easily ibuprofen and hinder its sorption onto sediment. Salinity also affected ibuprofen sorption due to decrease of the solubility of ibuprofen as salinity increased. In competitive sorption experiment, the addition of salicylic acid also led to enhance
\end{abstract}

Responsible editor: Roland Kallenborn

Sanghwa Oh

oh@ilem.or.kr

1 Institute of Livestock Environmental Management, Daejeon 34065, Republic of Korea

2 Department of Environmental Engineering, Kyungpook National University, Daegu 41566, Republic of Korea

3 Department of Civil Engineering, Kyungpook National University, Daegu 41566, Republic of Korea ibuprofen sorption. Conclusively, ibuprofen can be more easily sorbed onto the acidified sediments of river downstream, especially estuaries or near-shore environment with low DOM concentration.

Keywords Ibuprofen $\cdot$ Sorption $\cdot$ Sediment $\cdot \mathrm{pH} \cdot$ Dissolved organic matter $\cdot$ Salinity

\section{Introduction}

Recently, there has been a growing concern on the chronic toxicity of emerging compounds including pharmaceuticals present in the aquatic environment to nature and human being. However, few data are available for the fate of the pharmaceuticals and personal care products (PPCPs) in the watersediment system. Ibuprofen is widely used as a pain reliever and exists relatively persistent (half-life $=50$ days) in aquatic system so it has been reportedly detected frequently at high concentration of $0.9 \mu \mathrm{g} / \mathrm{L}$ in rivers and estuaries (Hilton et al. 2003; Thomas and Hilton 2004) but ibuprofen sorption onto sediment has not been considered significantly even though it has high octanol-water partition coefficient $\left(\log K_{\mathrm{ow}}\right.$ of 3.5 ) (Ternes 1998).

In polluted anaerobic sediments, microbiologically catalyzed sulfate reduction originates in sulfides (acid-volatile sulfide, AVS) and redox potential changes can promote sediment acidification by oxidation of sulfide to sulfate where about 0.3 to $3.0 \mathrm{pH}$ in sediment decreased (Di Nanno et al. 2007). Ionizable organic contaminants (IOCs) like ibuprofen exist in aqueous phase as ionic forms and/or neutral forms. The neutral species are predominant when $\mathrm{pH}<\mathrm{pKa}$ whereas the ionic species prevail when $\mathrm{pH}>\mathrm{pKa}$ (Chen et al. 2004). A lot of previous studies have identified that the hydrophobic sorption reaction is affected by the physicochemical properties 
of the compounds such as water solubility, octanol/water partition coefficient $\left(K_{\mathrm{ow}}\right)$, equilibrium coefficient $\left(K_{\mathrm{a}}\right)$, and some environmental conditions ( $\mathrm{pH}$, oxidation-reduction potential (ORP), and salinity) (Bowman et al. 2002; Wu and Sun 2010; Tremblay et al. 2005). To date, many of possible situations for ibuprofen sorption are still not fully understood or completely known (Scheytt et al. 2005).

Ibuprofen sorption onto sediment should not be expressed by simple reaction, which means there can be many parameters affecting the sorption. For example, the existence of dissolved organic matters (DOMs) can complicate the ibuprofen sorption mechanisms. Tremblay et al. (2005) reported that DOMs can affect the polycyclic aromatic hydrocarbons (PAHs) sorption because PAHs can also interact with DOMs. Therefore, PPCPs are also probably reacted with DOMs. Temporal and spatial gradients of salinity and DOMs in estuaries or coastal waters are known to affect the solubility of the hydrophobic compounds in water. Many researches also have reported that salinity also can affect sorption of hydrophobic organic compounds on the sediment in estuary or seawater (Oh et al. 2013; Tremblay et al. 2005; Wu and Sun 2010). However, studies on the behavior of PPCPs such as ibuprofen in the complex system with DOM, PPCP, water, and sediment system have almost not been up to now (Pan et al. 2009). Salinity also can affect sorption of hydrophobic organic compounds including ibuprofen on the sediment in estuary; however, there is no available information on the effect of salinity on PPCP sorption.

The aim of this study was to investigate the sorption of ibuprofen onto sediments under a variety of environmental conditions, for instance, $\mathrm{pH}(4.0,5.3$, and 7.0), DOM concentration, salinity ( 0 to 30 part per thousand (ppt)), and competitive sorption with other PPCPs (salicylic acid). The pH 5.3 is almost the same as the $\mathrm{pKa}$ of ibuprofen. Two sorption isotherm models such as linear and Freundlich models fitted the experimental sorption data of the ibuprofen. The parameters of the models such as distribution coefficient and Freundlich coefficient were investigated herein.

\section{Materials and methods}

\section{Sediment}

The uncontaminated sediment was taken from the surface layer (below $5 \mathrm{~cm}$ ) of a wetland in Changnyung, Republic of Korea (latitude: N 35.4397 and longitude: E 128.4836). The sediment was air-dried, sieved through a $212-\mu \mathrm{m}$ sieve (no. 70) to remove debris, homogenized, and then stored in sealed containers at room temperature before use.

The $\mathrm{pH}$ of the sediment was measured using a $\mathrm{pH}$ meter (Orion 290A) at $1 / 5(w / v)$ of sediment to solution ratio in deionized water. The particle size of the sediment was determined by combining sieving and sedimentation steps (Kettler et al. 2001). The point of zero charge (pzc) was also determined by a batch equilibration technique (Sparks et al. 1996). Brunauer, Emmett, and Teller (BET) surface area was measured by a surface area and pore size analyzer (Quantachrome, USA).

\section{Ibuprofen and buffer}

Ibuprofen sodium (Aldrich Chemical Co., >99 \%) and the radio-labelled RS-[carboxyl- ${ }^{14} \mathrm{C}$ ] ibuprofen (American Radiolabeled Chemicals, Inc. (ARC), $55 \mathrm{mCi} / \mathrm{mmol}$, >98 \%) were used as a sorbate and a radio-tracer, respectively. The physicochemical properties of ibuprofen are summarized in Table 1 . The ${ }^{14} \mathrm{C}$-ibuprofen stock solution was made by means of dilution of the radio-labelled ibuprofen solution with methanol to be about $20,000 \mathrm{cpm} / \mathrm{mL}$. The stock solution of
Table 1 Physical-chemical properties of the ibuprofen studied

\begin{tabular}{ll}
\hline & Ibuprofen \\
\hline Chemical formula & \\
Structure &
\end{tabular}


unlabelled ${ }^{12} \mathrm{C}$ ibuprofen was prepared with HPLC grade methanol for $10 \mathrm{mg} / \mathrm{L}$ of ibuprofen concentration in methanol.

Buffer solutions for $\mathrm{pH} 4.0$ and 7.0 were prepared as background solutions using the ${ }^{14} \mathrm{C}$ stock solution, the unlabeled ${ }^{12} \mathrm{C}$ stock solution, and electrolyte solution including $1 \mathrm{mM}$ $\mathrm{CaCl}_{2} \cdot 2 \mathrm{H}_{2} \mathrm{O}$ (Duksan Pure Chemical Co. Korea, $70 \%$ ), $0.5 \mathrm{mM} \mathrm{MgCl} 2 \cdot 6 \mathrm{H}_{2} \mathrm{O}$ (Duksan Chemical Co. Korea, $98 \%$ ), and $0.5 \mathrm{mM} \mathrm{Na}_{2} \mathrm{~B}_{4} \mathrm{O}_{7} \cdot 10 \mathrm{H}_{2} \mathrm{O}$ (Sigma Chemical Co., 99.5-105.0 \%) before each sorption experiment. The methanol to water ratio was lower than $0.2 \%(v / v)$ to prevent solvent effect for sorption (Zhang and $\mathrm{He} 2010$ ). Two hundred milligrams per liter of $\mathrm{NaN}_{3}$ (Duksan Pure Chemical Co., $97 \%$ ) was used as a bacterial inhibitor.

\section{Ibuprofen sorption onto sediment}

\section{Sorption procedure}

Ibuprofen sorption experiment was conducted at $25{ }^{\circ} \mathrm{C}$ in $40 \mathrm{~mL}$ amber vials (Fisher Co.) with Teflon-faced silicone septa. Four grams of the sediment was placed into the vials, and then electrolyte solutions were carefully added into the vials to prepare $0.1,0.2,0.4,0.6,0.8$, and $1.0 \mathrm{mg} /$ $\mathrm{L}$ of ibuprofen concentrations with initial radioactivity $\left({ }^{14} \mathrm{C}\right.$-ibuprofen) of about $2000 \mathrm{cpm} / \mathrm{mL}$ as a tracer. After carefully filling the vials with the solution minimizing the headspace, the vials were placed in a rotary shaker and shaken at $200 \mathrm{rpm}$ for $72 \mathrm{~h}$. The solution volume was determined gravimetrically. After mixing, the vials were centrifuged at $2000 \mathrm{rpm}$ for $20 \mathrm{~min}$ to separate sediment from solution. One milliliter of supernatant was decanted from the centrifugation and mixed with $10 \mathrm{~mL}$ of liquid scintillation cocktail (Ultima Gold, Sigma). The radioactivity of ${ }^{14} \mathrm{C}$-ibuprofen was determined by a liquid scintillation counter (LSC; EG\&G Wallac Co., 1220 Quantulus).

The equilibrium concentration of ibuprofen was calculated by Eq. (1) of the ratio of ${ }^{14} \mathrm{C}$-ibuprofen change between initial and final:

$C_{e}=C_{0} \times \frac{C_{(f R) e}}{C_{(i R) 0}}$

where $C_{0}$ and $C_{e}$ are initial and equilibrium concentrations of ibuprofen in solution $(\mathrm{mg} / \mathrm{L})$, respectively; $\mathrm{C}_{(i R) 0}$ is the concentration of ${ }^{14} \mathrm{C}$-ibuprofen in initial phase, and $\mathrm{C}_{(f R) e}$ is the concentration of ${ }^{14} \mathrm{C}$-ibuprofen in equilibrium phase (count by CPM or DPM).

The solid phase equilibrium concentrations were calculated by assuming all concentration changes in solution were caused by sorption onto the solid phase. The concentration of ibuprofen sorbed $q_{e}(\mathrm{mg} / \mathrm{kg})$ onto sediment was determined using the following equation (Amin 2008; Bajpai and Bhowmik 2010):

$q_{e}=\left(C_{0}-C_{e}\right) \frac{V}{W}$

where $C_{0}$ and $C_{e}$ are initial and equilibrium concentrations of ibuprofen in solution $(\mathrm{mg} / \mathrm{L})$, respectively; $q_{e}$ is the equilibrium concentrations of ibuprofen in sediment; $V$ is the volume of solution (L) and $W$ is the weight of sediment used (kg). All experiments were conducted in duplicate.

\section{Effect of $p H$}

If $\mathrm{pKa}$ values of PPCPs are in the range of experimental $\mathrm{pH}$, PPCPs can be protonated or deprotonated and thus exist as different species, such as cation, zwitterion, neutral, and anion (Pan et al. 2009). In the case of ibuprofen ( $\mathrm{pKa}=5.2)$, the ibuprofen exists as neutral species at $\mathrm{pH}<\mathrm{pKa}$, coexists as neutral and anionic species at $\mathrm{pH} \approx \mathrm{p} K \mathrm{a}$, and exists as anion species at $\mathrm{pH}>\mathrm{pKa}$.

In this study, we selected three $\mathrm{pH}$ conditions ( $\mathrm{pH} 4.0,7.0$, and 5.3) to investigate the difference in the sorption of ibuprofen with neutral, neutral/anionic, and anionic species onto sediment. The $\mathrm{pH}$ of the electrolyte solution was adjusted to 4.0 by acetate buffer solution $(0.01 \mathrm{M})$ and to 7.0 by phosphate buffer containing $6.74 \mathrm{~g} / \mathrm{L} \mathrm{K}_{2} \mathrm{HPO}_{4}+8.34 \mathrm{~g} / \mathrm{L}$ $\mathrm{KH}_{2} \mathrm{PO}_{4}$. And the initial $\mathrm{pH}$ of the solution without $\mathrm{pH}$ adjusting is 5.3 that is similar to $\mathrm{pKa}$ (5.2) of ibuprofen.

\section{Effect of dissolved organic matter and salinity}

Ibuprofen has been present in most of the rivers so it can be detected in estuaries and ocean water. Estuaries are mixing zones for fresh riverine and coastal ocean water masses featuring temporal and spatial gradients of temperature, salinity, and DOM concentration (Tremblay et al 2005).

To estimate the effect of DOMs on the sorption, ibuprofen sorption experiments were also carried out at $0.01,0.1$, and $1.0 \mathrm{M}$ of sodium citrate or urea concentration. The effect of the amount of added citrate and urea and $\mathrm{pH}$ (4 and 5.3) on the ibuprofen sorption was investigated and compared. To estimate the salinity effect on ibuprofen sorption, the sorption experiment was also conducted at $0,10,20$, and 30 ppt of salinity $(0,1.0,2.0$, and $3.0 \mathrm{~g} / \mathrm{L} \mathrm{NaCl}$ ). After sorption, the results from ibuprofen sorption with and without $\mathrm{NaCl}$ addition were compared.

\section{Competitive sorption}

Sorption of a mixture of ibuprofen and salicylic acid was conducted with mixing ibuprofen and salicylic acid of 1:1 weight ratio at the same concentrations such as $0,0.1,0.2$, $0.4,0.6,0.8$, and $1.0 \mathrm{mg} / \mathrm{L}$ of ibuprofen and salicylic acid. 
The reaction proceeded for $2 \mathrm{~h}$ at $25^{\circ} \mathrm{C}$ in an orbital shaker. After competitive sorption, the sorption result was compared to the single sorption results from ibuprofen and salicylic acid. The radio-labelled $\left[{ }^{14} \mathrm{C}\right]$ salicylic acid (American Radiolabeled Chemicals, Inc. (ARC), $55 \mathrm{mCi} / \mathrm{mmol}$ ) was also used as a radio-tracer.

\section{Sorption isotherm models}

The linear model and the Freundlich model were used to describe the sorption data, because the sorption isotherm patterns were shown almost linear. The linear model is expressed as follows:

$q=K_{d} C$

where $C(\mathrm{mg} / \mathrm{L})$ is the aqueous-phase equilibrium concentration, $q(\mathrm{mg} / \mathrm{kg})$ is the solid-phase equilibrium concentration, and $K_{\mathrm{d}}$ is the distribution coefficient in the linear model.

The Freundlich model is expressed as follows:

$q=K_{F} C^{N_{F}}$

where $K_{\mathrm{F}}\left[(\mathrm{mg} / \mathrm{kg}) /(\mathrm{mg} / \mathrm{L})^{N_{F}}\right]$ and $N_{\mathrm{F}}(-)$ are the Freundlich model coefficients.

The sorption model parameters were determined by using a commercial software package, Table Curve 2D® (version 5.0, SPSS, Inc.).

\section{Results and discussion}

\section{Sediment characteristics}

The $\mathrm{pH}$ of the sediment was about 5.49. From analysis of the sediment texture, the fractions of sand, silt, and clay in the sediment were measured at 19.9, 71.2, and 8.9\%, respectively, showing the order of silt $>$ sand $>$ clay. BET surface area of the sediment was $12.278 \mathrm{~m}^{2} / \mathrm{g}$, and pore volume and radius were $0.056 \mathrm{~mL} / \mathrm{g}$ and $18.793 \mathrm{~A}$, respectively. Total carbon and organic carbon contents were 0.76 and $0.53 \%$, respectively. Figure 1 depicts the plotting for estimating the pzc for the sediment, clearly displaying the intersection point at $\mathrm{pH}$ 5.64. It indicates that net charge of the sediment is positive when $\mathrm{pH}$ is lower than the pzc but negative at higher $\mathrm{pH}$.

\section{Effect of pH on ibuprofen sorption}

Pharmaceuticals exist in neutral form (hydrophobic) at $\mathrm{pH}$ below $\mathrm{pKa}$, but in anionic form (hydrophilic) at $\mathrm{pH}$ above $\mathrm{p} K \mathrm{a}$ (Bui and Choi 2009). Ibuprofen exists in the neutral form at $\mathrm{pH} 4$, the neutral/anionic form at $\mathrm{pKa}$, and the anionic form at $\mathrm{pH}$ 7. In this study, sorption of ibuprofen ( $\mathrm{pKa} 5.2$ ) onto sediment was performed at acidic $(\mathrm{pH} 4)$, around $\mathrm{pKa}(\mathrm{pH}$

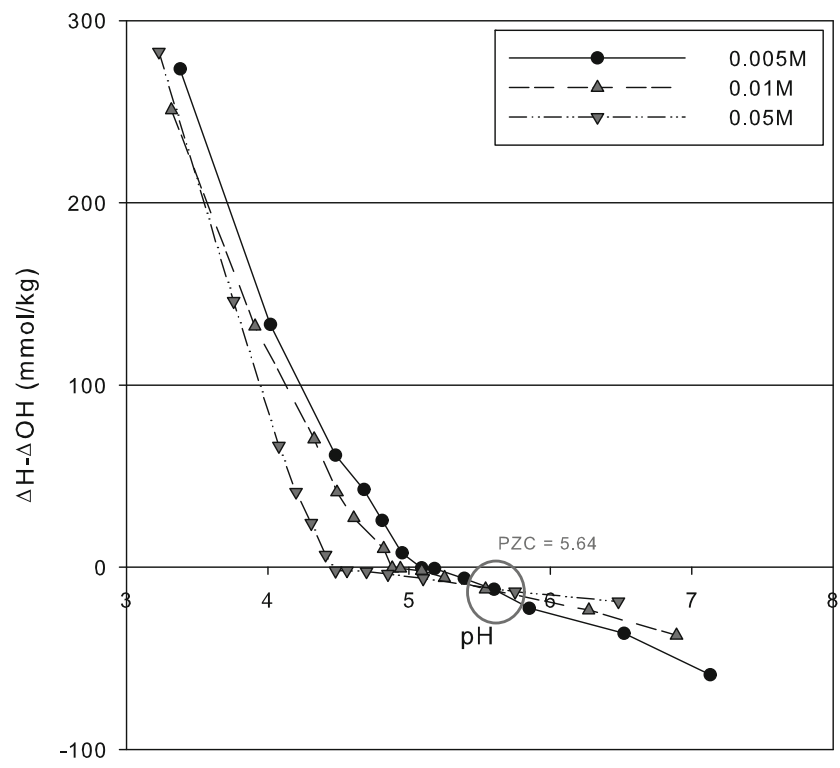

Fig. 1 The point of zero charge (pzc) of the sediment used in this study

5.3), and at neutral $\mathrm{pH}(\mathrm{pH} 7)$. Figure 2 shows the effect of $\mathrm{pH}$ on the sorption of ibuprofen onto the sediment at $\mathrm{pH} 4$, 5.3, and 7, and Table 1 presents parameters of the linear and the Freundlich models fitting experimental data.

Figure 2 shows the ibuprofen sorption onto sediment at $\mathrm{pH}$ 4, 5.3, and 7. The data are fitted by linear and Freundlich models and the fitted parameters are presented in Table 2. The $R^{2}$ of Freundlich model is almost the same but slightly higher than those of the linear model. Figure 2 shows that the strongly $\mathrm{pH}$-dependent sorption of ibuprofen exhibited almost linear and the ibuprofen sorption was the most favorable at $\mathrm{pH}$ 4 whereas it was almost not observed at $\mathrm{pH} 7$. Bui and Choi (2009) also reported that at $\mathrm{pH}$ below $\mathrm{pKa}$, acidic pharmaceuticals are neutral molecules, interacting with silica surface via non-electrostatic interaction involving hydrogen bonds. In this study, at $\mathrm{pH} 4$ below $\mathrm{pKa}$, the neutral ibuprofen was sorbed via non-electrostatic interaction with sediment surface. Although

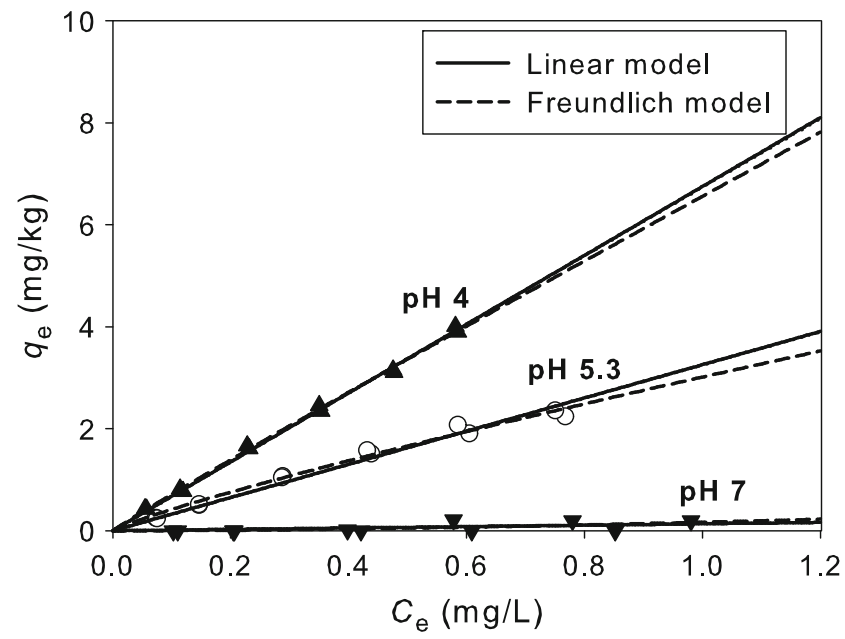

Fig. 2 Ibuprofen sorption isotherm onto sediment at $\mathrm{pH} 4,5.3$, and 7 
Table 2 Model parameters of ibuprofen sorption onto sediment $(n=6)$

\begin{tabular}{lllllll}
\hline $\mathrm{pH}$ & \multicolumn{2}{l}{ Linear model } & & \multicolumn{4}{l}{ Freundlich model } \\
\cline { 2 - 3 } \cline { 6 - 7 } & $K_{\mathrm{d}}$ & $R^{2}$ & & $K_{\mathrm{F}}$ & $N_{\mathrm{F}}$ & $R^{2}$ \\
\hline 4 & $6.8 \pm 0.1$ & 1.00 & & $6.6 \pm 0.1$ & $1.0 \pm 0.0$ & 1.00 \\
5.3 & $3.3 \pm 0.1$ & 0.97 & & $3.0 \pm 0.1$ & $1.2 \pm 0.1$ & 0.99 \\
7 & $0.1 \pm 0.0$ & 0.35 & & $0.2 \pm 0.1$ & $0.6 \pm 0.4$ & 0.38 \\
\hline
\end{tabular}

organic and mineral contents are not important in PPCP sorption because of the presence of functional groups in PPCP molecules (Pan et al. 2009), the neutral form is very important in sorption in this study. At $\mathrm{pH} 7$ above $\mathrm{pKa}$, ibuprofen was anionic (hydrophilic) and almost not sorbed onto sediment because the sediment was also negatively charged, which led to an electrostatic repulsion with each other (Bui and Choi 2009).

Table 2 shows that $K_{\mathrm{d}}$ values at $\mathrm{pH} 4,5.3$, and 7 are 6.8, 3.3 , and $0.1 \mathrm{~L} / \mathrm{kg}$, and $K_{\mathrm{p}}$ values are 6.6, 3.0, and 0.2, respectively, where $K_{\mathrm{d}}$ and $K_{\mathrm{p}}$ values at $\mathrm{pH} 4$ are higher than those at $\mathrm{pH} 5.3$ and 7, and $K_{\mathrm{d}}$ and $K_{\mathrm{p}}$ values at pH 5.3 are about in the middle of them at $\mathrm{pH} 4$ and $\mathrm{pH}$ 7. This indicates that ibuprofen sorption is strongly affected by its hydrophobicity (neutral form). Bui and Choi (2009) suggested that the pharmaceuticals are sorbed onto soil or sediment by hydrogen bonding between carboxyl groups of pharmaceuticals and silanol groups of soil or sediment particles which is in accordance with this study.

\section{Effect of dissolved organic matters on ibuprofen sorption}

Citrate and urea are considered the representative dissolved organic matters derived from plants and animals, respectively, and have high solubility in water. Gu et al. (2007) observed that PPCPs could bind with DOM in a complicated way because of the presence of functional groups. We conducted sorption isotherm of ibuprofen onto sediment in the presence of citrate and urea with 0 to $1.0 \mathrm{M}$ in solution to estimate the effect of citrate and urea on ibuprofen sorption (Fig. 3). The fitted parameters of linear and Freundlich models are also summarized in Table 3 . As seen in Table $3, K_{\mathrm{F}}$ values have the same pattern as $K_{\mathrm{d}}$ values because the fitting results are almost linear.

As shown in Fig. 3a (sodium citrate), c (urea) at $\mathrm{pH} 4$, the increase in sodium citrate concentration from 0.01 to $1.0 \mathrm{M}$
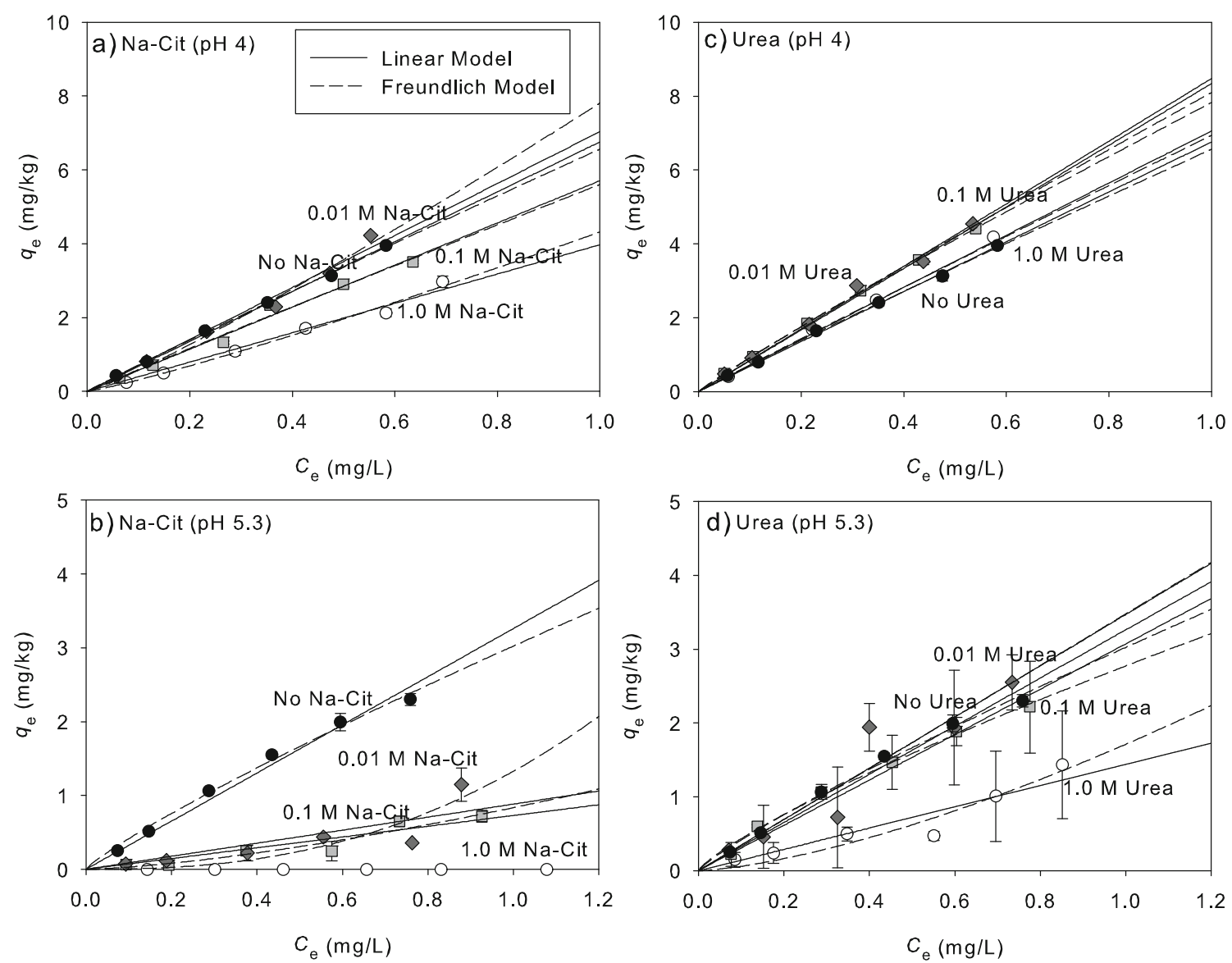

Fig. 3 Effect of dissolved organic matters on ibuprofen sorption at pH 4 and 5.3. a, b Sodium citrate. c, d Urea. Black circle, without Na-Cit or urea; black diamond, 0.01 M Na-Cit or urea; black square, 0.1 M Na-Cit or urea; white circle, 1.0 M Na-Cit or urea 
Table 3 Model parameters of ibuprofen sorption onto sediment affected by DOMs $(n=6)$

\begin{tabular}{|c|c|c|c|c|c|c|c|}
\hline \multirow[t]{2}{*}{ DOM } & \multirow[t]{2}{*}{$\mathrm{pH}$} & \multirow{2}{*}{$\begin{array}{l}\text { Conc. } \\
\text { (M) }\end{array}$} & \multicolumn{2}{|c|}{ Linear model } & \multicolumn{3}{|c|}{ Freundlich model } \\
\hline & & & $K_{\mathrm{d}}$ & $R^{2}$ & $K_{\mathrm{F}}$ & $N_{\mathrm{F}}$ & $R^{2}$ \\
\hline \multirow[t]{8}{*}{ Citrate } & \multirow[t]{4}{*}{4} & 0 & $6.8 \pm 0.1$ & 0.998 & $6.6 \pm 0.2$ & $1.0 \pm 0.0$ & 0.999 \\
\hline & & 0.01 & $7.0 \pm 0.3$ & 0.979 & $7.8 \pm 0.8$ & $0.9 \pm 0.1$ & 0.984 \\
\hline & & 0.1 & $5.7 \pm 0.2$ & 0.982 & $5.6 \pm 0.4$ & $1.0 \pm 0.1$ & 0.982 \\
\hline & & 1 & $4.0 \pm 0.1$ & 0.981 & $4.3 \pm 0.3$ & $0.9 \pm 0.1$ & 0.988 \\
\hline & \multirow[t]{4}{*}{5.3} & 0 & $3.3 \pm 0.1$ & 0.980 & $3.0 \pm 0.1$ & $1.2 \pm 0.1$ & 0.992 \\
\hline & & 0.01 & $0.9 \pm 0.1$ & 0.672 & $1.3 \pm 0.4$ & $0.4 \pm 0.2$ & 0.773 \\
\hline & & 0.1 & $0.7 \pm 0.1$ & 0.873 & $0.8 \pm 0.1$ & $0.7 \pm 0.2$ & 0.914 \\
\hline & & 1 & 0 & 0 & 0 & 0 & 0 \\
\hline \multirow[t]{8}{*}{ Urea } & \multirow[t]{4}{*}{4} & 0 & $6.8 \pm 0.1$ & 0.998 & $6.6 \pm 0.2$ & $1.0 \pm 0.0$ & 0.999 \\
\hline & & 0.01 & $8.5 \pm 0.2$ & 0.991 & $8.1 \pm 0.5$ & $1.1 \pm 0.1$ & 0.993 \\
\hline & & 0.1 & $8.3 \pm 0.1$ & 0.997 & $7.8 \pm 0.1$ & $1.1 \pm 0.0$ & 1.000 \\
\hline & & 1 & $7.1 \pm 0.2$ & 0.992 & $6.9 \pm 0.4$ & $1.0 \pm 0.1$ & 0.992 \\
\hline & \multirow[t]{4}{*}{5.3} & 0 & $3.3 \pm 0.1$ & 0.980 & $3.0 \pm 0.1$ & $1.2 \pm 0.1$ & 0.992 \\
\hline & & 0.01 & $3.5 \pm 0.3$ & 0.888 & $3.5 \pm 0.6$ & $1.0 \pm 0.3$ & 0.888 \\
\hline & & 0.1 & $3.1 \pm 0.1$ & 0.966 & $2.8 \pm 0.1$ & $1.2 \pm 0.1$ & 0.992 \\
\hline & & 1 & $1.4 \pm 0.1$ & 0.878 & $1.7 \pm 0.3$ & $0.7 \pm 0.2$ & 0.914 \\
\hline
\end{tabular}

led to decrease sorption of hydrophobic ibuprofen whereas urea addition did not decrease the ibuprofen sorption even when urea concentration was $1.0 \mathrm{M}$. This is probably due to little interaction among ibuprofen, urea, and sediment particles. Moreover, from 0.01 to $0.1 \mathrm{M}$ of urea concentration, $K_{\mathrm{d}}$ values ( 8.47 and $8.34 \mathrm{~L} / \mathrm{kg}$, respectively) of ibuprofen sorption increased a little bit compared to $K_{\mathrm{d}}$ without urea addition but at $1.0 \mathrm{M}$ urea, $K_{\mathrm{d}}$ value $(7.06 \mathrm{~L} / \mathrm{kg})$ was almost the same as the value $(6.76 \mathrm{~kg} / \mathrm{L})$ without urea addition. This result suggests that ibuprofen sorption can be affected by "salting out effect" (Gu et al. 2007; Oh et al. 2013) if urea was not reacted with ibuprofen.

But as sodium citrate was added, ibuprofen sorption gradually decreased. $K_{\mathrm{d}}$ values at citrate concentrations of $0,0.01$, 0.1 , and $1.0 \mathrm{M}$ were $6.76,7.04,5.71$, and $3.98 \mathrm{~L} / \mathrm{kg}$, respectively (see Table 3). Citrate has three carboxyl groups. Therefore, it is possible that some of ibuprofen was bound to the carboxyl groups. If citrate-ibuprofen complex was formed, the complex also exists anionic and soluble form causing gradual decrease in ibuprofen sorption. At $\mathrm{pH}$ 5.3, about half of ibuprofen is also negatively charged. The ibuprofen sorption was remarkably interrupted by citrate addition at only $0.01 \mathrm{M}$ and at high concentration of urea $(1.0 \mathrm{M})$.

\section{Effect of salinity on ibuprofen sorption}

Sorption isotherm of ibuprofen and the relationship between $K_{\mathrm{d}}$ (and $K_{\mathrm{F}}$ ) and salinity are depicted in Fig. 4 and Table 4. Figure 4 illustrates that the sorption behavior of ibuprofen on

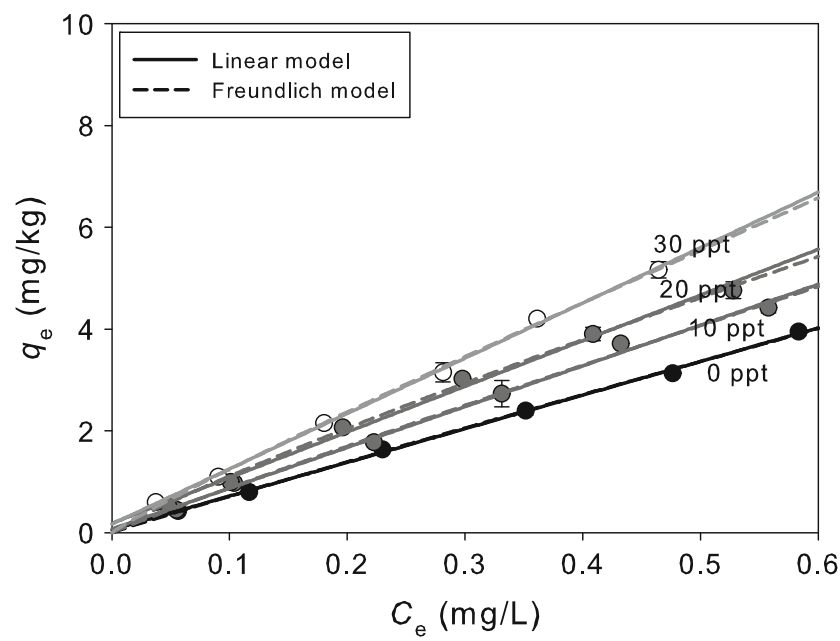

Fig. 4 Effect of salinity on ibuprofen sorption

sediment followed linear isotherm at all different salinities. $K_{\mathrm{d}}$ for ibuprofen sorption increased with salinity due to "salting out" effect, which is caused by high salinity resulting in high compressive water-water interaction, decreasing water solubility, and less cavitation of water molecule (Turner 2003; Oh et al. 2013). Oh et al. (2013) also reported that $\log K_{\text {ow }}$ of hydrophobic PAHs increased with salinity, indicating that hydrophobic materials may be sorbed easily onto sediment at high salinity. For hydrophobic pollutants, therefore, sorption onto particulate matter is one of the dominant phase transfer processes affecting their movement and fate in the environment (Wu and Gschwend 1986). You et al. (2010) also reported that the increase in salinity results in a decrease in the solubility of organic compounds and thus an increase in sorption coefficient. This experiment was conducted at $\mathrm{pH} 4$ where neutral form of ibuprofen exists, indicating that there is a high possibility of ibuprofen trapped in sediments acidified in estuary or coastal conditions due to high salinity.

\section{Bi-solute competitive sorption of ibuprofen and salicylic acid}

Bi-solute competitive sorption experiments for ibuprofen and salicylic acid were performed. As expected, when the two pharmaceuticals compete for sorption at the same site of

Table 4 Model parameters for ibuprofen sorption onto sediment at 0 , 10,20 , and 30 ppt of salinity $(n=6)$

\begin{tabular}{|c|c|c|c|c|c|c|}
\hline \multirow[t]{2}{*}{$\mathrm{pH}$} & \multirow[t]{2}{*}{ Salinity (ppt) } & \multicolumn{2}{|c|}{ Linear model } & \multicolumn{3}{|c|}{ Freundlich model } \\
\hline & & $K_{\mathrm{d}}$ & $R^{2}$ & $K_{\mathrm{F}}$ & $N_{\mathrm{F}}$ & $R^{2}$ \\
\hline \multirow[t]{4}{*}{4} & 0 & $6.8 \pm 0.1$ & 0.998 & $6.6 \pm 0.2$ & $1.0 \pm 0.0$ & 0.999 \\
\hline & 10 & $8.2 \pm 0.1$ & 0.994 & $7.9 \pm 0.4$ & $1.0 \pm 0.0$ & 0.995 \\
\hline & 20 & $9.5 \pm 0.2$ & 0.989 & $8.5 \pm 0.3$ & $0.9 \pm 0.0$ & 0.997 \\
\hline & 30 & $11.4 \pm 0.2$ & 0.995 & $10.6 \pm 0.4$ & $0.1 \pm 0.0$ & 0.998 \\
\hline
\end{tabular}


sediment, the sorption of each ibuprofen and salicylic acid was less than that in single-solute system. Single- and bisolute sorption isotherm is depicted in Fig. 5, and the sorption parameter of the experimental data fitted to linear and Freundlich models are summarized in Table 5.

In comparison with single-solute sorptions, $K_{\mathrm{d}}$ values for single- and bi-solute sorption for both solutes are increased from 6.76 to $9.53 \mathrm{~L} / \mathrm{kg}$ for ibuprofen and from 16.98 to $20.19 \mathrm{~L} / \mathrm{kg}$ for salicylic acid, respectively. Therefore, the $K_{\mathrm{d}}$ ratio between bi-solute sorption and single-solute sorption was 1.41 for ibuprofen and 1.19 for salicylic acid, respectively. This indicates that the sorption of ibuprofen and salicylic acid was enhanced as concentrations of them increased. There was a synergistic effect on ibuprofen sorption. Some portion of the ibuprofen in solution also could be sorbed or attached on the particles of salicylic acid which has higher sorption affinity, $K_{\mathrm{d}}$, than ibuprofen (see Fig. 5). That is probably one of the reasons for the increase in ibuprofen sorption.

\section{Conclusion}

Ibuprofen sorption onto sediment was investigated under several environmental conditions such as $\mathrm{pH}$ change, dissolved organic matter, salinity, and competitive sorption to understand the fate of ibuprofen in water-sediment system. Ibuprofen was not sorbed onto sediment at $\mathrm{pH} 7$ whereas it was favorably sorbed at $\mathrm{pH} 4$. Therefore, if sediment is acidified, the ibuprofen changes its form from anionic to neutral that can be easily sorbed onto the sediment. The presence of citrate from 0.01 to $1.0 \mathrm{M}$ interrupted ibuprofen sorption; furthermore, the interruption was enhanced at $\mathrm{pH} 5.3$ as compared to $\mathrm{pH}$ 4.0. However, urea did not interrupt but enhanced the ibuprofen sorption. Salinity also enhanced ibuprofen sorption. In bi-solute competitive sorption, addition of salicylic

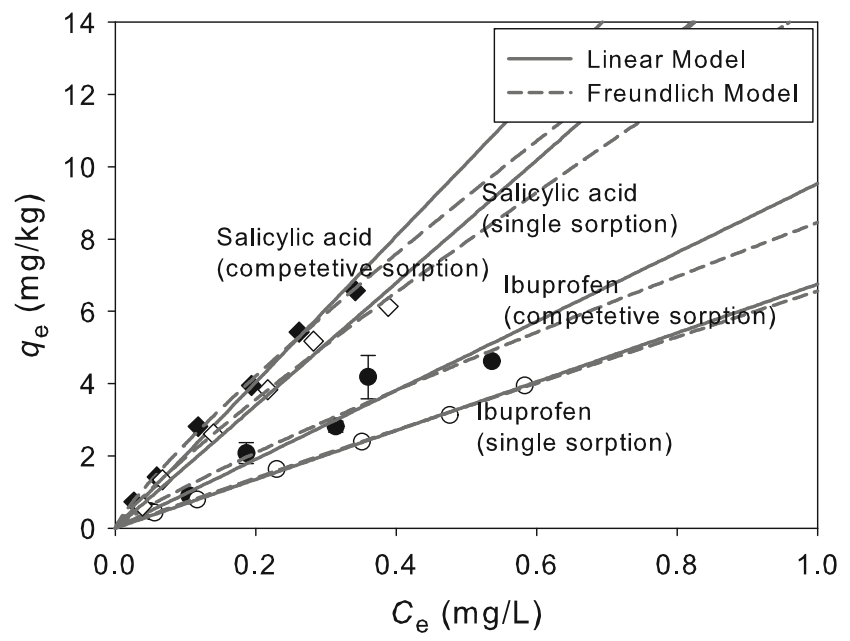

Fig. 5 Competitive sorption of ibuprofen and salicylic acid

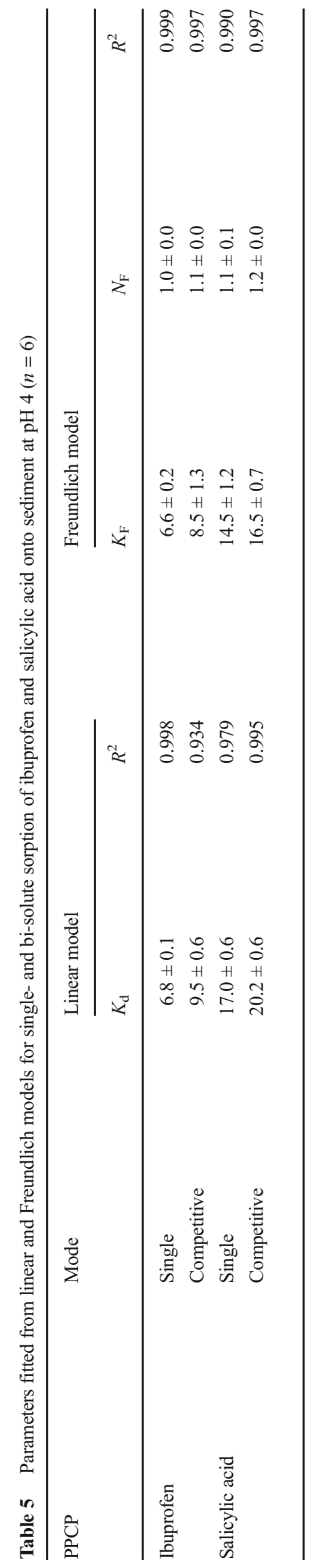


acid could boost the ibuprofen sorption; thus, the $K_{\mathrm{d}}$ and $K_{\mathrm{F}}$ also increased. Conclusively, ibuprofen sorption can be found at acidified sediments located around river downstream, estuaries, or near-shore marine environment with low DOM concentration.

Acknowledgments This research was supported by the National Research Foundation of Korea (NRF) grant funded by the Korea Government (MEST) (No. NRF-2011-0015098).

Open Access This article is distributed under the terms of the Creative Commons Attribution 4.0 International License (http:// creativecommons.org/licenses/by/4.0/), which permits unrestricted use, distribution, and reproduction in any medium, provided you give appropriate credit to the original author(s) and the source, provide a link to the Creative Commons license, and indicate if changes were made.

\section{References}

Amin NL (2008) Removal of reactive dye from aqueous solutions by the adsorption onto activated carbons prepared from sugarcane bagasse pith. Desali 223:152-161. doi:10.1016/j.desal.2007.01.203

Bajpai SK, Bhowmik M (2010) Adsorption of diclofenac sodium from aqueous solution using polyaniline as a potential sorbent. I. Kinetic studies. J Appl Polym Sci 117:3615-3622. doi:10.1002/app.32263

Bowman JC, Zhou JL, Readman JW (2002) Sediment-water interactions of natural oestrogens under estuarine conditions. Mar Chem 77: 263-275. doi:10.1016/S0304-4203(02)00006-3

Bui TX, Choi H (2009) Adsorptive removal of selected pharmaceuticals by mesoporous silica SBA-15. J Hazard Mater 168:602-608. doi:10.1016/j.jhazmat.2009.02.072

Chen H, Zhou W, Zhu K, Zhan H, Jiang M (2004) Sorption of ionizable organic compounds on HDTMA-modified loess soil. Sci Total Environ 326:217-223

Di Nanno MP, Curutchet G, Ratto S (2007) Anaerobic sediment potential acidification and metal release risk assessment by chemical characterization and batch resuspension experiments. J Soils Sediments 7: 187-194. doi:10.1065/jss2007.04.220

Gu C, Karthikeyan KG, Sibley SD, Pedersen JA (2007) Complexation of the antibiotic tetracycline with humic acid. Chemosphere 66:14941501. doi:10.1016/j.chemosphere.2006.08.028

Hilton MJ, Thomas KV, Ashton D (2003) Targeted monitoring programme for pharmaceuticals in the aquatic environment. R\&D
Technical Report P6-012/06/TR. Environmental Agency, United Kingdom

Kettler TA, Doran JW, Gilbert TL (2001) Simplified method for soil particle-size determination to accompany soil-quality analyses. Soil Sci Soc Am J 65:849-852. doi:10.2136/sssaj2001.653849x

Oh S, Wang Q, Shin WS, Song DI (2013) Effect of salting out on the desorption-resistance of polycyclic aromatic hydrocarbons (PAHs) in coastal sediment. Chem Eng J 225:84-92. doi:10.1016/j.cej.2013.03.069

Pan B, Ning P, Xing B (2009) Part V-sorption of pharmaceuticals and personal care products. Environ Sci Pollut Res 16:106-116. doi:10.1007/s11356-008-0052-x

Scheytt Y, Mersmann P, Lindstadt R, Heberer T (2005) Determination of sorption coefficients of pharmaceutically active substances carbamazepine, diclofenac, and ibuprofen, in sandy sediments. Chemosphere 60:245-253. doi:10.1016/j.chemosphere.2004.12.042

Sparks DL, Page AL, Helmke PA, Loeppert RH, Soltanpour PN, Tabatabai MA, Johnston CT, Sumner ME (1996) Methods of soil analysis. Part 3-chemical methods. Soil Science Society of America, Inc. USA

Ternes TA (1998) Occurrence of drugs in German sewage treatment plants and rivers. Water Res 32:3245-3260. doi:10.1016/S0043-1354(98)00099-2

Thomas KV, Hilton MJ (2004) The occurrence of selected human pharmaceutical compounds in UK estuaries. Mar Pollut Bull 49:436444. doi:10.1016/j.marpolbul.2004.02.028

Tremblay L, Kohl SD, Rice JA, Gagne JP (2005) Effects of temperature, salinity, and dissolved humic substances on the sorption of polycyclic aromatic hydrocarbons to estuarine particles. Mar Chem 96:2134. doi:10.1016/j.marchem.2004.10.004

Turner A (2003) Salting out of chemicals in estuaries: implications for contaminant partitioning and modelling. Sci Total Environ 314-316: 599-612. doi:10.1016/S0048-9697(03)00076-7

Wu S, Gschwend PM (1986) Sorption kinetics of hydrophobic organic compounds to natural sediments and soils. Environ Sci Technol 20: 717-725. doi:10.1021/es00149a011

Wu W, Sun H (2010) Sorption-desorption hysteresis of phenanthreneeffect of nanopores, solute concentration, and salinity. Chemosphere 81:961-967. doi:10.1016/j.chemosphere.2010.07.051

You C, Jia C, Pan G (2010) Effect of salinity and sediment characteristics on the sorption and desorption of perfluorooctane sulfonate at sediment-water interface. Environ Pollut 158:1343-1347. doi:10.1016/j.envpol.2010.01.009

Zhang J, He M (2010) Effect of structural variations on sorption and desorption of phenanthrene by sediment organic matter. J Hazard Mater 184:432-438. doi:10.1016/j.jhazmat.2010.08.123 